\title{
Analisis Pengaruh Marketing Activity dan Working Capital Terhadap \\ Profitabilitas di PT. Krakatau Steel \\ Tahun 2010-2018
}

\author{
${ }^{1}$ LMS. Kristiyanti, ${ }^{2}$ Abdul Haris Romdhoni, ${ }^{3}$ Alfiana Kristi \\ ${ }^{1,2,3}$ Sekolah Tinggi Ilmu Ekonomi AAS Surakarta, Indonesia \\ ${ }^{1}$ Email korenpondensi: Ims.kristiyanti@yahoo.co.id
}

\begin{abstract}
This observation is aimed to know that there is influence between marketing activity and working capital to profitability in PT. Krakatau Steel. This uses trimester financial statements from the last trimester financial statement in 2010 until first trimester financial statement in 2018 as samples in observation.This is a quantitative observation in which it uses 1 population and 30 samples in total. This uses secondary data as source which is downloaded from official website of company and some websites establishing its information. The technique in collecting data is a non-participant observation which doesn't require researcher to work financial statements out directly. This observation uses multiples linear regression analysis. The result of observation shows that there is not any influence between marketing activity (which represented by marketing expense, company size and company age) and profitability partially in PT. Krakatau Steel year of 2010 to 2018, however it shows that working capital influences profitability in PT. Krakatau Steel year of 2010 to 2018 partially. As for the result in simultan, both of marketing activity and working capital has influence to profitability.
\end{abstract}

Keywords : marketing expense, company age, company size, working capital, profitability

\begin{abstract}
Abstrak
Penelitian ini bertujuan untuk mengetahui adanya pengaruh marketing activity dan working capital terhadap profitabilitas di PT. Krakatau Steel. Penelitian ini menggunakan data laporan keuangan triwulanan perusahaan dari triwulan terakhir tahun 2010 hingga triwulan awal 2018 sebagai sampel dalam penelitian.Penelitian ini merupakan penelitian kuantitatif yang menggunakan 1 populasi dan 30 sampel. Sumber data yang digunakan adalah sumber data sekunder yaitu berupa laporan keuangan yang diambil dari website perusahaan tersebut sendiri dan beberapa situs lain yang memuat penerbitan laporan perusahaan tersebut. Teknik pengumpulan data yang digunakan dalam penelitian ini adalah observasi non participant, dimana peneliti tidak ikut secara langsung dalam penulisan laporan keuangan. Analisis yang digunakan dalam penelitian ini adalah analisis regresi linier berganda.Hasil penelitian menunjukkan bahwa marketing activity baik yang diwakili oleh marketing expense, company size dan company age tidak berpengaruh secara parsial terhadap profitabilitas di PT. Krakatau Steel periode 2010-2018, sedangkan working capital berpengaruh secara parsial terhadap profitabilitas di PT. Krakatau Steel periode 2010 hingga 2018. Selain itu, hasil penelitian menunjukkan bahwa secara simultan marketing activity dan working capital berpengaruh terhadap profitabilitas di PT. Krakatau Steel tahun 2010 hingga 2018.
\end{abstract}

Kata Kunci: marketing expense, company age, company size, working capital, profitabilitas

Saran Sitasi: Kristiyanti, L., Romdhoni, A., \& Kristi, A. (2019). Analisis Pengaruh Marketing Activity dan Working Capital Terhadap Profitabilitas di PT. Krakatau Steel Tahun 2010-2018. Jurnal Akuntansi dan Pajak, 19(1), 21-28. doi: http://dx.doi.org/10.29040/jap.v20i1.542

DOI: http://dx.doi.org/10.29040/jap.v20i1.542 


\section{Pendahuluan}

Perusahaan terjamin kelangsungan hidupnya, berkembang dan mampu bersaing, apabila perusahaan dapat menjual produknya dengan harga yang menguntungkan pada tingkat kuantitas yang diharapkan serta mampu mengatasi tantangan para pesaing. Menurut American Marketing Association (2015), kegiatan pemasaran merupakan aktivitas, kebiasaan dan proses untuk menciptakan, berkomunikasi, memberikan, dan bertukar penawaran yang memiliki nilai bagi pelanggan, klien, mitra kerja, dan masyarakat pada umumnya. Saat ini kegiatan pemasaran menjadi komponen yang tidak terpisahkan dalam suatu organisasi (Daukseviciute, Valainis, \& Vilkaite, 2011). Penciptaan persepsi merek dan harga sangat penting, karena persepsi merek dan persepsi harga memiliki pengaruh positif signifikan terhadap variabel perceived value, dimana perceived value sendiri memiliki pengaruh positif terhadap variabel intends to repurchase (Kusdyah, 2012).

Untuk melakukan kegiatan pemasaran, perusahaan membutuhkan biaya (Serenia, 2015:269). Artikel Raymond (2012) menyatakan kegiatan pemasaran dapat mencapai 10 persen dari penjualan perusahaan, dimana 10 persen tersebut sangat penting untuk selalu dipantau produktivitasnya. Hasil penelitian Moormand \& Rust (1999) kegiatan marketing memiliki pengaruh juga didukung oleh penelitian lain seperti penelitian Kim \& Jaewoo (2013) yang memiliki kesimpulan bahwa beban pemasaran yang dilakukan dapat mengangkat penjualan pada semua industri yang diteliti. Namun, aktivitas marketing tidak hanya terbatas dalam secara nyata perusahaan mengeluarkan uang untuk beban pemasaran saja, tetapi erat kaitannya juga dengan umur perusahaan yang mencerminkan bagaimana perusahaan dapat bersaing (Kim \& Jaewoo, 2013). Aktivitas pemasaran tidak berhenti pada beban pemasaran (marketing expense) dan umur perusahaan (company age) saja, peneliti juga menemukan bahwa ukuran perusahaan (company size) juga mempengaruhi aktivitas marketing yang dilakukan perusahaan. Menurut Kartika (dalam Efriana Mustika, 2012), umur perusahaan menunjukkan seberapa lama perusahaan mampu bertahan di industri tertentu. Semakin lama perusahaan dapat bertahan, kemungkinan perusahaan untuk mengembalikan investasi akan semakin besar karena sudah berpengalaman. Kegiatan marketing menunjukkan eksistensi suatu perusahaan untuk berkompetisi dalam suatu pasar. Menurut Kim dan Jaewoo (2013), Perusahaan dengan ukuran yang lebih besar memiliki efektivitas dalam mendanai kinerja marketing yang kemudian berpengaruh pada penjualan dan laba perusahaan jika dibandingkan dengan perusahaan dengan ukuran yang lebih kecil.

Profitabilitas perusahaan tidak hanya bergantung dari kegiatan marketing perusahaan tersebut saja karena modal kerja (working capital) dapat berpengaruh bagi perusahaan. Modal kerja yang cukup memungkinkan suatu perusahaan dapat menjalankan aktivitasnya dengan lancar dan mampu mengatasi kesulitan yang mungkin terjadi.

Pengelolaan modal kerja, tidak lepas dari pengelolaan aktiva lancar dan utang lancar perusahaan. Jika suatu perusahaan tidak bisa mempertahankan modal kerja yang cukup, kemungkinan perusahaan akan berada dalam keadaan tidak mampu membayar kewajibankewajiban yang jatuh tempo dan terancam mengalami kebangkrutan. Oleh karena itu, pengelolaan modal kerja yang efektif dan efisien akan mampu meningkatkan profitabilitas, yaitu kemampuan perusahaan untuk menghasilkan laba selama periode tertentu (Irawati, 2006: 58). Terdapat beberapa ukuran yang digunakan untuk melihat kondisi profitabilitas suatu perusahaan, antara lain adalah gross profit margin, net profit margin, return on invesment dan return on equity.

Fenomena terjadi pada laporan keuangan periode 2010-2018 PT Krakatau Steel adalah mengalami kenaikan modal kerja dan marketing activity namun mengalami penurunan profitabilitas, maka dilakukan penelitian kembali 
mengenai pengaruh marketing activity (aktivitas pemasaran) dan working capital (modal kerja) terhadap profitabilitas dengan obyek penelitian di PT Krakatau Steel dalam Tahun 2010 - 2018.

\subsection{Rumusan Masalah}

Atas dasar permasalahan pada penelitian terdahulu, maka masalah yang hendak dijawab melalui penelitian ini adalah sebagai berikut :

a. Apakah marketing activity mempengaruhi profitability perusahaan secara parsial?

b. Apakah working capital mempengaruhi profitability perusahaan secara parsial?

c. Apakah marketing activity dan working capital secara simultan mempengaruhi profitability perusahaan?

\subsection{Hipotesis}

Kerangka pemikiran dari penelitian ini adalah:

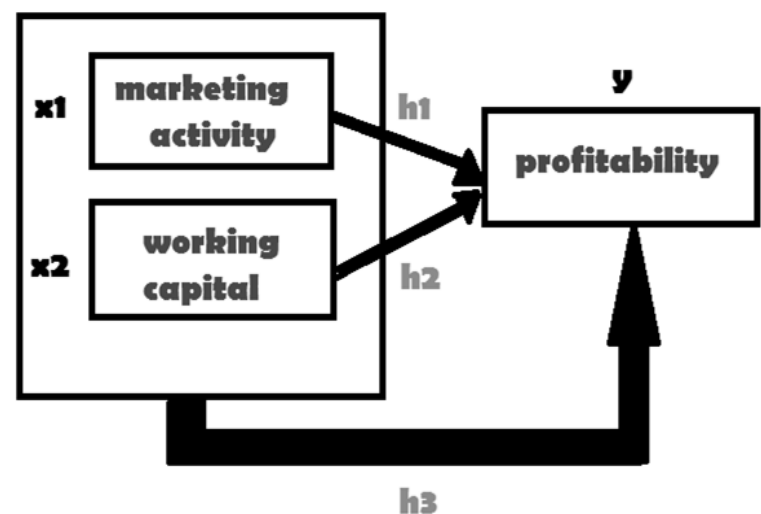

Gambar 1

Kerangka Pemikiran

PT. Krakatau Steel mengalami kenaikan modal kerja dan marketing activity namun mengalami penurunan profitabilitas, hal ini bertolak belakang dengan penelitian-penelitian terdahulu yang pernah dilakukan. Oleh karena argumen tersebut, maka dapat dirumuskan hipotesis sebagai berikut

H1 : Ada pengaruh marketing activity terhadap profitabilitas di PT. Krakatau Steel

$\mathrm{H} 2$ : Ada pengaruh working capital dengan profitabilitas di PT. Krakatau Steel

H3 : Ada pengaruh marketing activity dan working capital terhadap profitabilitas di PT. Krakatau Steel

\section{Metode Penelitian}

Populasi dari penelitian ini laporan keuangan PT. Krakatau Steel, sebagai sampel adalah laporan keuangan triwulanan PT. Krakatau Steel dari triwulan terakhir tahun 2010 sampai dengan triwulan awal tahun 2018. Variabel yang menjadi obyek penelitian:

a. Independen variable (variabel $\mathrm{X}$ ) yaitu marketing activity dan working capital.

b. Dependent variable (variabel Y) yaitu profitability.

\subsection{Metode Analisa Data}

Analisis yang digunakan untuk mengetahui pengaruh marketing activity dan working capital terhadap profitabilitas, menggunakan analisis regresi linier berganda. Tahap-tahap pengolahan data meliputi:

a. Penghitungan marketing expense ratio, besaran company size dan company age sebagai variabel independen pertama yang tergabung sebagai marketing activity yang berasal dari informasi dan laporan keuangan perusahaan.

b. Penghitungan working capital sebagai variabel independen yang kedua.

c. Perhitungan rasio profitability (ROS)

d. Uji Statistik Deskriptif

e. Uji Asumsi Klasik

1) Uji Normalitas

Untuk menguji apakah variable pengganggu atau residual pada model regresi memiliki distribusi normal. Uji statistik normalitas yang digunakan Kolmogrov Smirnov, dimana signifikansinya menggunakan tabel pembanding Kolmogorov smirnov.

2) Uji Multikolinearitas

Untuk menguji apakah ditemukan korelasi antar variable independen pada model regresi.

3) Uji Autokorelasi

Untuk menguji apakah terdapat korelasi antara kesalahan penganggu pada periode $\mathrm{t}$ dengan kesalahan penganggu pada periode t-1 (sebelumnya) pada model regresi linier. 
4) Heteroskedastisitas

Uji heteroskedastisitas untuk menguji apakah terjadi ketidaksamaan varians dari residual satu pengamatan ke pengamatan yang lain pada model regresi.

\subsection{Pengujian Hipotesis}

Pengujian hipotesis dengan menggunakan alat Statistical Packager for Social Science (SPPS) versi 23.0 dengan tahapan:

a. Regresi Linier Berganda

Untuk mengetahui pengaruh variabel indipenden terhadap variabel dependen pada hipotesis yang telah dibuat.

b. Uji Signifikan Parameter Individual (uji statistik t)

Untuk mengetahui variabel-variabel independen secara parsial berpengaruh nyata atau tidak terhadap variabel dependen. Hasil hitung (t hitung) akan dibandingkan dengan tabel $t$ atau biasa disebut $t$ tabel.

c. Uji Signifikansi Simultan (uji statistik F)

Untuk menunjukkan semua variabel indipenden mempunyai pengaruh secara bersama-sama terhadap variabel dependen. Hasil hitung ( $\mathrm{f}$ hitung) dalam penelitian ini akan dibandingkan dengan tabel $\mathrm{f}$.

d. Uji Koefisien Determinasi (uji statistik $R^{2}$ ) Untuk mengetahui seberapa besar hubungan dari beberapa variabel dalam pengertian yang lebih jelas. Koefisien determinasi akan menjelaskan seberapa besar perubahan atau variasi suatu variabel bisa dijelaskan oleh perubahan atau variasi pada variabel yang lain.

\section{Pembahasan Hasil Penelitian}

\subsection{Uji Statistik Deskriptif}

Nilai median dan standar deviasi merupakan ukuran untuk melihat apakah variabel-variabel dalam penelitian pada uji statistic deskriptif ini memiliki distribusi normal atau tidak. Nilai median dan standar deviasi akan dibandingkan. Data berdistribusi normal adalah yang memiliki nilai median lebih besar dari standar deviasi.

Tabel 1

Tabel Perbandingan Nilai Median Dan Standar Deviasi

\begin{tabular}{|l|c|c|c|c|}
\hline \multicolumn{1}{|c|}{ Variabel } & Median & Std Deviasi & Hasil & Keterangan \\
\hline log_marketingexpense & 4.2692 & .23615 & $>$ & Normal \\
\hline log_companysize & 6.4596 & .10630 & $>$ & Normal \\
\hline log_companyage & 1.6425 & .02178 & $>$ & Normal \\
\hline SMEAN(log_workingcapital) & 5.3944 & .26599 & $>$ & Normal \\
\hline SMEAN(log_ros) & .3869 & .34103 & $>$ & Normal \\
\hline
\end{tabular}

\subsection{Uji Asumsi Klasik}

\subsubsection{Uji Normalitas}

Konsep dasar dari uji normalitas Kolmogorov smirnov adalah dengan membandingkan distribusi data dengan distribusi normal baku. Penerapan pada uji Kolmogorov Smirnov adalah jika signifikansi di bawah 0,05 berarti data yang akan diuji mempunyai perbedaan yang signifikan dengan data normal baku, artinya data tersebut tidak normal.

Dari pengujian didapatkan nilai signifikansi empat variabel bebas terhadap variabel terikat sebesar 0.200. Karena nilai signifikansi 0,200 lebih besar daripada 0,05, maka distribusi data adalah normal.

\subsubsection{Uji Multikolineralitas}

Uji multikolinearitas bertujuan untuk menguji apakah terdapat korelasi antar variable independen pada model regresi. Penelitian ini mengambil keputusan berdasarkan nilai tolerance hasil uji.

Hasil uji multikolinearitas yang dilakukan, nilai tolerance dari marketing expense sebesar 0,866 , company size sebesar 0,142, company age sebesar 0,132 dan working capital sebesar 0,806 . Hasil uji ini memberikan informasi bahwa terjadi multikolinearitas pada vaiabel company age namun tidak terjadi multikolinearitas pada variabel yang lain yaitu marketing expense, company size dan working capital. 


\subsubsection{Uji Heteroskedastisitas}

Hasil uji heteroskedastisitas nilai signifikansi pada marketing expense sebesar 0,800, company age sebesar 0,501, company size sebesar 0,448 dan working capital sebesar 0,841. Nilai signifikansi tersebut kemudian dibandingkan dengan 0,05 yang mana jika nilai signifikansi lebih kecil dari 0,05 maka terjadi heteroskedastisitas dan apabila nilai signifikansi lebih besar dari 0,05 maka tidak terjadi heteroskedastisitas.

\subsubsection{Uji Autokorelasi}

Metode Durbin Watson dipilih untuk melakukan uji autokorelasi dalam penelitian ini. Hasil pengujian berupa DW sebesar 2,123. Selanjutnya nilai ini dibandingkan dengan nilai tabel signifikansi 5\%, jumlah sampel 30 dan jumlah variabel independen $4(\mathrm{k}=4)$, maka diperoleh nilai dU sebesar 1,7386 .

Dari hasil tersebut telah diketahui bahwa nilai DW sebesar 2,149 terletak diantara batas bawah 1,7386 dan batas atas 2,2614, maka tidak terdapat autokorelasi pada data-data yang diuji.

\subsection{Uji Hipotesis}

\subsubsection{Uji regresi linier berganda}

\section{Tabel 2}

Tabel Rangkuman Uji Regresi Linier Berganda

\begin{tabular}{||l|l|c|c|c|c|c|}
\hline & $\begin{array}{c}\mathrm{T} \\
\text { hitung }\end{array}$ & $\begin{array}{c}\mathrm{T} \\
\text { tabel }\end{array}$ & $\begin{array}{c}\mathrm{F} \\
\text { hitung }\end{array}$ & $\begin{array}{c}\mathrm{F} \\
\text { tabel }\end{array}$ & Hasil \\
\hline Uji T & $\begin{array}{l}\text { Marketing } \\
\text { expense }\end{array}$ & -1.312 & 2,060 & & $\begin{array}{l}\text { Tidak } \\
\text { berpengaruh }\end{array}$ \\
\cline { 2 - 6 } \\
$\begin{array}{l}\text { Company } \\
\text { size }\end{array}$ & 0.157 & 2,060 & & & $\begin{array}{l}\text { Tidak } \\
\text { berpengaruh }\end{array}$ \\
\hline $\begin{array}{l}\text { Company } \\
\text { age }\end{array}$ & -0.442 & 2,060 & & & $\begin{array}{l}\text { Tidak } \\
\text { berpengaruh }\end{array}$ \\
\hline $\begin{array}{l}\text { Working } \\
\text { capital }\end{array}$ & 2.307 & 2,060 & & & Berpengaruh \\
\hline \multicolumn{2}{|c|}{ Uji F } & & & 2.939 & 2,74 & Berpengaruh \\
\hline
\end{tabular}

Hasil uji regresi liner berganda yang dilakukan, secara parsial variabel marketing activity yang terdiri dari variabel marketing expense, company age dan company size tidak berpengaruh terhadap profitabilitas, sedangkan variabel working capital memiliki pengaruh terhadap profitabilitas. Hasil pengujian secara simultan, maka keseluruhan variabel bebas memiliki pengaruh terhadap variabel bebas profitabilitas.

\subsubsection{Uji t}

Uji parsial $t$ menggunakan perbandingan $t$ tabel dan $\mathrm{t}$ hitung sebagai dasar pengambilan keputusan. $\mathrm{t}$ tabel yang menempati urutan $(\alpha / 2 ; n-K-1)$ atau di urutan $(0,025 ; 25)$ yaitu sebesar 2,060 .

Tabel 3

Tabel Perbandingan t Hitung dan $t$ Tabel

\begin{tabular}{|c|c|c|c|c|}
\hline Variabel & T hitung & T tabel & Hasil & Keterangan \\
\hline $\begin{array}{c}\text { Marketing } \\
\text { expense }\end{array}$ & -1.312 & 2,060 & $<$ & $\begin{array}{c}\text { Tidak } \\
\text { berpengaruh }\end{array}$ \\
\hline Company size & 0.157 & 2,060 & $<$ & $\begin{array}{c}\text { Tidak } \\
\text { berpengaruh }\end{array}$ \\
\hline Company age & -0.442 & 2,060 & $<$ & $\begin{array}{c}\text { Tidak } \\
\text { berpengaruh }\end{array}$ \\
\hline $\begin{array}{c}\text { Working } \\
\text { capital }\end{array}$ & 2.307 & 2,060 & $>$ & Berpengaruh \\
\hline
\end{tabular}

Hasil output dapat diketahui bahwa nilai t hitung marketing expense adalah $-1,312$, company size sebesar 0,157 , company age sebesar $-0,442$ dan working capital sebesar 2,307. Hasil tersebut dibandingkan dengan $\mathrm{t}$ tabel maka sebagai kesimpulan bahwa secara parsial variabel marketing activity yang terdiri dari variabel marketing expense, company age dan company size tidak berpengaruh terhadap profitabilitas, sedangkan variabel working capital memiliki pengaruh terhadap profitabilitas. Hasil company age yang berpengaruh negatif terhadap profitabilitas ini juga didukung penelitian sebelumnya oleh Ongwibowo dan Hartane (2015). Sedangkan hasil company size yang berpengaruh negatif terhadap profitabilitas ini didukung dengan penelitian sebelumnya oleh Serenia dan Hartane (2015).

\subsubsection{Uji F}

Pengambilan keputusan uji $\mathrm{F}$ menggunakan perbandingan $\mathrm{F}$ hitung dengan $\mathrm{F}$ tabel. $\mathrm{F}$ tabel menempati $(4,26)$ yaitu diangka 2,74 . Output uji $F$ memiliki nilai $\mathrm{F}$ hitung sebesar 2,939. F hitung lebih besar daripada $\mathrm{F}$ tabel maka hipotesis diterima, yaitu marketing activity (marketing expense, company age dan company size) dan working capital secara simultan berpengaruh terhadap profitabilitas.

\subsubsection{Uji koefisien determinasi}

Output uji koefisien determinasi dalam pengujian ini memiliki nilai koefisien determinasi sebesar 0,320. Artinya variabel independen memiliki pengaruh sebesar 32\% terhadap variabel dependen. Sisa sebesar $68 \%$ tidak mempengaruhi variabel dependen yang diakibatkan oleh faktor lain. 


\section{Kesimpulan}

Berdasarkan hasil penelitian dan pembahasan, maka dapat disimpulkan:

1. Marketing activity yang diwakili oleh marketing expense secara parsial tidak berpengaruh terhadap profitabilitas di PT. Krakatau Steel periode 2010-2018. Hal ini dibuktikan dengan perolehan nilai $\mathrm{t}$ hitung sebesar -1,312 yang lebih kecil daripada $\mathrm{t}$ tabel sebesar 2,060.

2. Marketing activity yang diwakili oleh company size secara parsial tidak berpengaruh terhadap profitabilitas di PT. Krakatau Steel periode 2010-2018. Hal ini dibuktikan dengan perolehan nilai $\mathrm{t}$ hitung sebesar 0.157 yang lebih kecil daripada $t$ tabel sebesar 2,060.

3. Marketing activity yang diwakili oleh company age secara parsial tidak berpengaruh terhadap profitabilitas di PT. Krakatau Steel periode 2010-2018. Hal ini dibuktikan dengan perolehan nilai t hitung sebesar -0,442 yang lebih kecil daripada $\mathrm{t}$ tabel sebesar 2,060.

4. Working capital secara parsial berpengaruh terhadap profitabilitas di PT. Krakatau Steel periode 2010-2018. Hal tersebut dibuktikan dengan perolehan nilai t hitung sebesar 2,307 yang lebih besar daripada $\mathrm{t}$ tabel sebesar 2,060 .

5. Hasil uji menggunakan uji $\mathrm{F}$ dalam penelitian ini menunjukkan bahwa secara simultan marketing activity (yang diwakili oleh marketing expense, company size dan company age) beserta working capital berpengaruh terhadap profitabilitas di PT. Krakatau Steel periode 2010-2018. Hal ini dibuktikan dengan perolehan nilai $F_{\text {hitung }}$ sebesar 2,939 yang lebih besar daripada $F_{\text {tabel }}$ sebesar 2,74.

6. Nilai $R$ square dalam penelitian ini sebesar 0,320, dapat disimpulkan bahwa marketing activity (yang diwakili oleh marketing expense, company size dan company age) beserta working capital memiliki pengaruh sebesar $32 \%$ terhadap profitabilitas di PT. Krakatau Steel periode 2010-2018. Sisanya sebesar $68 \%$ tidak mempengaruhi profitabilitas yang mungkin diakibatkan oleh faktor lain.

\section{Daftar Pustaka}

Adebisi Sunday. A, Babatunde Bayode.O. (2011). Strategic Influence of Promotional Mix on Organization Sale Turnover in The Face of Strong Competition (a Case Study of 7up Company). Business Intelligence JournalJuly, 2011 Vol.4 No.2 University of Ado Ekiti: Ekiti State, Nigeria.

Ali, Hasan . (2013). Marketing dan Kasus-Kasus Pilihan. Yogyakarta: CAPS (Center For Academic Publishing Service).

American Marketing Association. (2009). Definition of Marketing. Retrieved on April, $1^{\text {st }} 2018$ from American Marketing Association:

https://www.ama.org/AboutAMA/Pages/Def inition-of-Marketing.aspx

Arikunto, S. (2006). Prosedur penelitian : Suatu Pendekatan Praktik. Jakarta : Rineka Cipta

Basu Swasta, Dharmesta dan Irawan, (2008) Manajemen Pemasaran Modern, Liberty, Yogyakarta.

Best, R. (2008). Marketing Based Management. Pearson

Brigham, Eugene F And Joel F. Houston. (2006). Dasar-Dasar Manajemen Keuangan. Jakarta: PT. Selemba Empat.

Cookham, M. (2009). Marketing and the 7Ps. Journal of The Chartered Institute of Marketing. Retrieved October 12, 2014, from: http://cim.co.uk/marketingresource.

Daft, L. Richard. (2012). Era Baru Manajemen. Jakarta: Salemba Empat.

Daukseviciute, I., Valainis, A., \& Vilkaite, N. (2011). Concenptualization of The Effectiveness of Marketing Tools. Intellectual Economics, 5(10), 200-211.

Dogan, M. (2013). Does Firm Size Affect The Firm Profitability? Evidance from Turkey. Research Journal of Finance and Accounting,4(4), 53 - 59. 
Fahmi, Irham (2011). Analisa Laporan Keuangan. Bandung: Alfabeta.

Ferry, M.G., dan Jones, W.H. (1979). Determinants of Financial Structure: A new methodological approach. Journal of Finance.01 XXXXIV(3).

Ganguli, S. (2009). Impact of $R \& D$ Versus Marketing on Sales Growth in Indian Industrial Sectors. The IUP Journal of Management Research VIII, 55 - 64.

Gitman. (2001). Manajemen Keuangan 2, Edisi Ke dua. Jakarta: Prehallindo.

Goo, K. \& Karadag, I. (2006). Comparing Market-segment-profitability Analysis with Department Profitability Analysis as Hotel Marketing-decision Tools. Cornell University VOL. 47, hal 103-127.

Hanafi, Mamduh dan Halim, Abdul. (2010). Analisis Laporan Keuangan. Yogyakarta: Yogyakarta: Penerbit UPP Sekolah Tinggi Ilmu Manajemen YKPN.

Irawati, Susan. (2006). Manajemen Keuangan. Bandung: Pustaka.

Kerlinger. (2006). Asas-Asas Penelitian Behaviour. Edisi 3, Cetakan 7. Yogyakarta: Gadjah Mada University Press.

Kim, Y \& Joo, J. (2013). The Moderating Effect of Product Market Competition in The Relationship Between Advertising Expenditures and Sales. Journal of Applied Business Research VOL 29, hal 1061-1076.

Kusdyah, Ike. (2012). Persepi Harga, Persepsi Merek, Persepsi Nilai, dan Keinginan Pembelian Ulang Jasa Clinic Kesehatan (Studi Kasus ERHA Clinic Surabaya). Jurnal Manajemen Pemasaran, Vol. 7, No. 1, April 2012.

Larry, B. (2005). Linking Marketing to Profitability. Journal of The Practical Accountan VOL. 1, hal 12-20.

Loderer, C. \& Waelchli, U. (2010). Firm Age and Performance. Journal of Financial Management VOL. 7, hal2-52.

Luo, X., \& de Jong, P. (2012). Does Advertising Spending Really Work? The Intermedate Role of Analysts in the Impact of Advertising on Firm Value. Journal of Academy Marketing. Science,40, 605-624.
Mardalis. (2009). Populasi dan Sampel Penelitian.

http://triatra.wordpress.com/2011/04/05/pop ulasi-dan-sampel-penelitian/. Diakses tanggal 5 April 2018.

Mahendru, M., \& K. De, K. (2014). Does Dvertising Expenditure Impact Firm Value; A Case of Indian FMCG Industry. Global Journal of Management and Business Research: C.Finance 14 (1), 7-18.

Moorman, C., \& Rust, R. (1999). The Role of Marketing. Journal of Marketing VOL. 63, hal180-197.

Martono, Agus \& Harjito. (2001). Manajemen Keuangan. Jakarta: PT. Asdi Mahasatya.

Philip Kotler, Kevin Keller. (2007). Manajemen Pemasaran, Edisi ke dua belas. Jakarta: Indexs.

Raymond. (2012). Improve Your Marketing ROI. Raymond's View, hal 22-24

Riyanto, Bambang. (2004). Dasar - dasar Pembelanjaan Perusahaan, Edisi 4, Yogyakarta: BPFE

Sartono, Agus. (2001). Manajemen Keuangan dan Teori Aplikasi. Yogyakarta: BPFE.

Seftianne dan Ratih Handayani. (2011). Faktorfaktor yang Mempengaruhi Struktur Modal Pada Perusahaan Publik Sektor Manufaktur.Jurnal Bisnis dan Akuntansi, 13(1), 39-56.

Sekaran, Uma. (2011). Research Methods for Business, Edisi I dan II. Jakarta: Salemba Empat.

Serenia, Sonia dan Elsye Hatane, Saarce. (2015). Pengaruh Kegiatan Marketing Terhadap Profitabilitas dan Nilai Perusahaan Properti dan Real Estate di BEI. Business Accounting Review, VOL.3,NO.1, Januari 2015, hal 268-279.

Sugiyono. (2009). Metode Penelitian Kuantitatif, Kualitatif dan R\&D, Bandung: Alfabeta.

Sutrisno. (2012). Manajemen Keuangan Teori, Konsep dan Aplikasi. Yogyakarta: EKONISIA. 
Jurnal Akuntansi dan Pajak, 20(01), 2019, 28

Suwito, Edy dan Arleen Herawaty. (2005). Analisis Pengaruh Karakteristik Perusahaan terhadap Tindakan Perataan Laba yang dilakukan oleh Perusahaan yang Terdaftar di Bursa Efek Jakarta. Simposium Nasional Akuntansi VIII Solo. 15-16 September.

Syamsudin, Lukman. (2011). Manajemen Keuangan Perusahaan. Jakarta: Rajawali Pers.

Ulum, Ihyaul. (2009). Intellectual Capital: Konsep dan Kajian Empiris. Yogyakarta: Graha Ilmu.
Trisnawati Ongkowibowo, Debora dan Elsye Hatane, Saarce. (2015). Pengaruh Marketing Activity Terhadap Profitability dan Market Value Perusahaan Retail dan Produksi Besar. Business Accounting Review, VOL.3,NO.1, Januari 2015, hal 362-373.

Weston dan brigham . (1986). Fundamental of Financial Statement, Edisi Tujuh. Prentice Hall. New Jersey.

Wheelen, T \& Hunger, D. (2012). Strategic Management and Business Policy : Toward Global Sustainability Thirtheenth,. New York : Pearson. 